\title{
Customer Satisfaction Analysis Based On SERVQUAL Method to Determine Service Level of Academic Information Systems on Higher Education
}

\author{
I.G.P. Asto Buditjahjanto \\ Electrical Engineering Department \\ Universitas Negeri Surabaya \\ Indonesia \\ Correspondence: asto@unesa.ac.id
}

\begin{abstract}
Higher education institutions such as universities or institutes that create graduate students with high qualifications must be able to provide the best services to their stakeholders. One kind of higher education service is academic information system services. The service quality level of the academic information system in a university can be decided by measuring the level of users' perception and the level of users' expectations that can be fulfilled. As an organization that offers academic information system services, the university must be able to measure the level of academic information system services as an approach to ensure the quality of services. This study aims to determine the level of customer satisfaction index in terms of service of higher education academic information systems using the service quality method. The service quality method is used to identify academic information system services that are analyzed based on the service quality dimensions. The results show that the value of the customer satisfaction index is $77.37 \%$ which refers to the satisfied category.
\end{abstract}

Keywords: customer satisfaction index; service quality; weighted gap score; academic information system; quality improvement

Article info: submitted April 13, 2020, revised June 15, 2020, accepted July 22, 2020

\section{Introduction}

Higher education is an organization or institution that educates students and produces graduates with high ability and competence. As an institution that produces graduates with high qualifications, higher education such as the university should be able to properly manage the services available so that the available services can be delivered maximally to its stakeholders.

The users of university service are students, lecturers, and university employees. The biggest portion of service users is students. Therefore, a significant amount of effort is needed to improve the value of education services continuously by focusing on the interests of increasing service user satisfaction. Various types of higher education services include academic information system services, library services, English services, sports facilities services, health services, and others need an evaluation to ensure the quality of such services. A university which is an organization that offers various services should be evaluated in terms of service level. As mentioned before, students become the biggest users in experiencing a higher education service. Student satisfaction is often used to assess the quality of education in a university. Therefore, the quality of education can be determined by meeting the needs and expectations of students.

To understand the quality of services, institutions require ways or methods to measure the provided service so that it can be identified whether the service level is good or not. Various concepts and models have been developed to measure user satisfaction. According to [1], Servqual is a superior method in analyzing a service perceived by users toward the difference of their perception and their expectation of what they feel about a product or a service. Servqual tests five dimensions of service quality namely tangible, responsiveness, assurance, empathy, and reliability. Each dimension is a measure of service quality for both perceptions and expectations. It is further stated in [2], [3] that the use of Servqual can be applied to understand the level of the gap that exists between perceptions and expectations among users in the banking service quality content. In the hospitality sector, [4] and [5] state that Servqual can be used to measure the quality of hotel management on the perceptions and expectations of customers. Obtaining the gaps information is beneficial for quality improvements of the hotel management. 
Moreover, Servqual can also be used in transportation services [6], fitness services [7], online service [8], [9], and health services [10]. Even though the Servqual method has been used in various fields, the use of the in Higher Education such as universities to evaluate provided services is still low. Authors in [11], [12] used Servqual to find out how to calculate the quality of class services by viewing students as customers and having broad implications for stakeholders in the delivery of higher education. Authors in [13] stated that the use of Servqual can analyze the perception gap between students and staff on the quality of educational services.

This research focuses on the Academic Information System (SIAKADU) service that is available at the State University of Surabaya. The research problem is how to measure the level of satisfaction of the users of academic information system service at a State University in Surabaya. Wherein these levels of user satisfaction of academic information system services have not been yet measured properly. Service improvements are only based on suggestions and complaints boxes from users so that service improvements have not been well planned.

This study used Servqual to determine the Customer Satisfaction Index (CSI) by analyzing each dimension of service quality in the academic information system. This study also developed a questionnaire instrument in accessing the five dimensions of Servqual. The questionnaire instrument is developed using 7 Likert scales in its measurement. The purpose of this study is to determine the level of CSI in the academic information system service of a State University of Surabaya using the Servqual method. The CSI results can then be used as a basis for implementing the quality improvement of the academic information system at the State University of Surabaya.

\section{Literature Review}

\section{a. Service Quality}

Authors in [14] defined service quality as follows: service is as perceived by the user toward service or product, while perceived quality is a comparison between user perception and expectation on a service or a product. User expectations are the services expected, arising from a need. Whereas, perception is how customers view and assess the provided services whether it is appropriate or not. Therefore, the interpretation of customer needs is very crucial for a service provider organization. This is if the performance of an organization excels in service, it can strengthen competitiveness and establish relationships with customers, consolidate brands, and communicate with markets. Servqual is a method or way to evaluate service quality in an organization and can be used to measure the level of user satisfaction with the Servqual dimensions.

Servqual has been widely applied to improve the quality of an organization. Authors in [15], [16] applied Servqual dimension in the food business to measure the satisfaction of customers. In the health sector, [10] use Servqual to evaluate patient fulfillment with the quality of hospital health services. The results of his research can show which Servqual attributes have a high level of user satisfaction and which Servqual attributes have a low level of user satisfaction. In the banking sector, [17] conducted a study of the relationship between Servqual and user satisfaction at banks. The results of his research disclosed that the multidimensional Servqual scale correlates positively and significantly with the unidimensional customer satisfaction scale. In the field of aviation, research conducted by [18] identified Servqual using the framework of Servqual with several modifications. Furthermore, Servqual is used as an antecedent to measure customer satisfaction, a condition that can generate loyalty towards an airline brand. From the development of Servqual attributes, an inquiry of the relationship between Servqual and user satisfaction on airlines can be investigated.

\section{b. Customer Satisfaction Index (CSI)}

Referring to [19] the CSI is a way to calculate the level of overall user satisfaction by looking at the level of importance of each product and/or service attribute. The CSI is an applied index to calculate the level of overall user satisfaction by considering the level of importance of each attribute through measurement [20]. In this research, the computation of CSI can be calculated through the following steps [21]:

Step 1: Calculate the Mean Importance Score (MIS) of each attribute

$M I S=\frac{\sum_{i=1}^{n} Y_{i}}{n}$

Where :

$\mathrm{n}=$ total respondents

$Y_{i}=$ the expectation value of $i$-th attribute

Step 2: Calculate Weight Factors (WF) per attribute. Furthermore, this WF is a MIS percentage value each attribute to the total MIS of all attributes.

Step 3: Calculate the Mean Satisfaction Score (MSS) of each attribute using equation (2).

$M S S=\frac{\sum_{i=1}^{n} X_{i}}{n}$

Where:

$\mathrm{n}=$ total respondents

$\mathrm{X}_{\mathrm{i}}=$ the expectation value of $\mathrm{i}$-th attribute

Step 4: Calculate the Weight Score (WSi) in equation (3) for each attribute. WSi is a multiplication between WFi and MSSi, so that

$W S_{i}=W F_{i} x M S S_{i}$

Where: $\mathrm{i}=$ the $\mathrm{i}$-th attribute 
Step 5: Calculate the Customer Satisfaction Index using equation (4).

$$
C S I=\frac{\sum_{i=1}^{p} w S_{i}}{K} \times 100 \%
$$

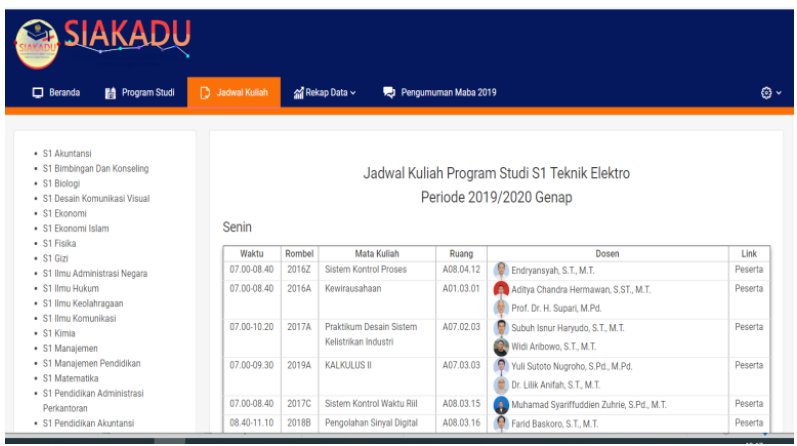

Figure 1. The display of Academic Information Systems

\section{Method}

The questionnaire instrument was developed based on the Servqual method conducted by [22] which refers to the dimensions of Servqual. In filling out the questionnaire, Likert scale with a scale of 7 is used. The aim of using the scale is to promote respondents to provide an assessment more precise to their preferences. Table 1 shows the results of the developed questionnaire.

Table 1. The Questionnaire Instrument

\begin{tabular}{|c|c|c|}
\hline Dimension & No & Indicator \\
\hline \multirow[t]{3}{*}{ Tangible } & 1 & $\begin{array}{l}\text { The SIAKADU display has features that } \\
\text { are easy to understand }\end{array}$ \\
\hline & 2 & $\begin{array}{l}\text { The SIAKADU system can be accessed } \\
\text { anywhere and anytime }\end{array}$ \\
\hline & 3 & $\begin{array}{l}\text { The SIAKADU system has the same } \\
\text { features on the mobile and web versions }\end{array}$ \\
\hline \multirow[t]{3}{*}{ Reliability } & 4 & $\begin{array}{l}\text { The SIAKADU system has no bugs } \\
\text { (errors) when accessed }\end{array}$ \\
\hline & 5 & $\begin{array}{l}\text { The SIAKADU has a real-time } \\
\text { information system }\end{array}$ \\
\hline & 6 & $\begin{array}{l}\text { The SIAKADU provides valid } \\
\text { information }\end{array}$ \\
\hline \multirow[t]{3}{*}{ Responsiveness } & 7 & $\begin{array}{l}\text { The SIAKADU features works according } \\
\text { to their functionality }\end{array}$ \\
\hline & 8 & $\begin{array}{l}\text { The SIAKADU error handling and } \\
\text { repairing on systems is done quickly }\end{array}$ \\
\hline & 9 & $\begin{array}{l}\text { The SIAKADU system is easily accessed } \\
\text { using various devices such as PCs, } \\
\text { smartphones, tablets }\end{array}$ \\
\hline \multirow[t]{3}{*}{ Assurance } & 10 & $\begin{array}{l}\text { The SIAKADU system has a security } \\
\text { system that is guaranteed against user data }\end{array}$ \\
\hline & 11 & $\begin{array}{l}\text { The SIAKADU system has a user guide } \\
\text { that can be accessed by users }\end{array}$ \\
\hline & 12 & $\begin{array}{l}\text { The SIAKADU guarantees the privacy of } \\
\text { each user }\end{array}$ \\
\hline \multirow[t]{2}{*}{ Empathy } & 13 & $\begin{array}{l}\text { The SIAKADU uses grammar that is easy } \\
\text { to understand }\end{array}$ \\
\hline & 14 & $\begin{array}{l}\text { The SIAKADU has a procedure that is } \\
\text { easily understood by users }\end{array}$ \\
\hline
\end{tabular}

Prior to collect respondent's data, a validity and reliability test are applied to the questionnaire. The questionnaire is compiled and developed based on the 5 dimensions of Servqual having indicators of 14 question items. The questionnaire is tested on 30 respondents to get the value of validity and reliability. Table 2 shows the validity of all indicators. The validity test results show that the calculated correlation value from the 1 st indicator to the 14th indicator is greater than the table correlation value which is 0.361 for $\mathrm{N}=30$. Therefore, it can be said that all 14 question items are valid.

Table 2. Validity and reliability questionnaire test results

\begin{tabular}{cccc}
\hline Variable & $\begin{array}{c}\text { Cronbach's } \\
\text { Alpha }\end{array}$ & No & $\mathbf{r}_{\mathbf{x y}}$ \\
\hline Tangible & 0.6453 & 1 & 0.701 \\
& & 2 & 0.481 \\
Reliability & 0.8259 & 4 & 0.833 \\
& & 5 & 0.651 \\
& & 6 & 0.861 \\
& 0.7600 & 7 & 0.781 \\
& & 8 & 0.670 \\
Assurance & 0.7961 & 10 & 0.670 \\
& & 11 & 0.871 \\
& & 12 & 0.727 \\
Empathy & 0.9268 & 13 & 0.728 \\
& & 14 & 0.842 \\
\hline
\end{tabular}

Then the reliability test from the questionnaire was conducted. A questionnaire is said to be reliable if the calculated value is greater than the table value. By using SPSS, a calculation is performed to calculate the reliability value with an alpha value of $5 \%$. Table 2 also shows the results of the reliability test for each variable. The calculation results show that the calculated value is greater than the table value of 0.361 with $\mathrm{N}=30$. So it can be stated that all variables are reliable.

The population of respondents was all students at the State University of Surabaya. The questionnaire is sent to selected respondents via a simple random sampling method. The questionnaire data collection was carried out online and offline. The questionnaire is compiled on the Google form for those who fill in online, and the implementation of offline data collection is done face to face to fill out the questionnaire. Notification of filling out the questionnaire was sent via e-mail and WhatsApp to 260 respondents. A total of 225 respondents filled the entire indicator in the questionnaire from various faculties and levels while the rest ( 35 respondents) did not fill at all or only partially filled in so that their involvement in filling the questionnaire could be ignored. The population of respondents was all students at a State University of Surabaya. 


\section{Result}

The composition of respondents is as follows: the number of male respondents with a percentage of $74.2 \%$ and female respondents with a percentage of $25.8 \%$. With the largest number of respondents in the engineering faculty at $41.3 \%$ and the smallest was the sports science faculty at $0.4 \%$. Table 3 shows the distribution of data from the respondents.

Then the calculation of the mean value of each Servqual dimension is calculated. For example, it can be seen in table 4 on the tangible dimensions with indicator number 1 that the mean value of expectation is 5.91 and the mean value of perception is 5.59. Then the Gap value can be obtained with a value of -0.31 . Likewise, for the calculation of other Servqual dimensions in this research.

Next, by using steps (1) and (2), the Mean Importance Score (MIS) can be obtained as shown in column 2 of Table 4 and Weight Factors (WF) can be obtained as shown in column 5 of Table 4. Then the Mean calculation is performed Satisfaction Score (MSS) in step (3), the MSS value can be obtained as seen in column 3 of Table 4 . Then step 4 is used to calculate Weight Score (WS) which is the multiplication of WF with MSS. WS calculation results are shown in column 6 of Table 4. The last step is step 5 used to calculate the CSI obtained with a value of $77.37 \%$.

Table 3. Data distribution from respondents

\begin{tabular}{lcc}
\hline \multicolumn{1}{c}{ Characteristics } & Number of Respondents & Percentage (\%) \\
\hline Age (years) & 225 & \\
$18-25$ year & 225 & 100 \\
Total & & 100 \\
Gender & 167 & \\
Male & 58 & 74,2 \\
Female & 225 & 25,8 \\
Total & & 100 \\
Faculty & 32 & \\
Faculty of Science Education & 33 & 14,2 \\
Faculty of Language and Art & 93 & 14,7 \\
Faculty of Engineering & 19 & 41,3 \\
Faculty of Social and Law & 29 & 8,4 \\
Faculty of Mathematics and Natural Sciences & 17 & 12,9 \\
Faculty of Economics & 2 & 7,6 \\
Faculty of Sports Sciences & 225 & 0,9 \\
\hline Total & & 100 \\
\hline
\end{tabular}

Table 4. Servqual calculation results

\begin{tabular}{cccccc}
\hline No & MIS & MSS & GAP & WF & WS \\
& Scale 7 & Scale 7 & Score & Score & Score \\
\hline 1 & 5.91 & 5.59 & -0.32 & 6.78 & 37.90 \\
2 & 6.07 & 5.63 & -0.44 & 6.96 & 39.20 \\
3 & 6 & 4.81 & -1.19 & 6.88 & 33.11 \\
4 & 6.12 & 4.68 & -1.44 & 7.02 & 32.86 \\
5 & 6.12 & 5.25 & -0.87 & 7.02 & 36.86 \\
6 & 6.47 & 5.78 & -0.69 & 7.42 & 42.90 \\
7 & 6.33 & 5.6 & -0.73 & 7.26 & 40.67 \\
8 & 6.48 & 5.69 & -0.79 & 7.43 & 42.30 \\
9 & 6.44 & 5.37 & -1.07 & 7.39 & 39.67 \\
10 & 5.82 & 5.02 & -0.8 & 6.68 & 33.52 \\
11 & 6.05 & 5.21 & -0.84 & 6.94 & 36.16 \\
12 & 6.49 & 5.58 & -0.91 & 7.45 & 41.54 \\
13 & 6.44 & 5.91 & -0.53 & 7.39 & 43.66 \\
14 & 6.43 & 5.59 & -0.84 & 7.38 & 41.23 \\
\hline Total & 87.17 & - & - & - & 541.58 \\
Customer Satisfaction Index (CSI) & & & & & 77.37 \\
\hline
\end{tabular}


Table 4 shows the process of calculating the CSI in analyzing 14 indicators from the Servqual dimension. Table 4 also shows the Gap scores of the 14 indicators on Servqual. Overall, the gap scores of the 14 indicators show negative values. This shows that the users' expectations are not fulfilled toward the users' perception of academic information system services. The highest negative value gap score is indicator number 4 which is The SIAKADU system has no bugs (errors) when it is accessed, and the lowest negative value Gap is an indicator for number 1 which is the SIAKADU display has features that are easy to understand. By knowing the highest negative gap score of the indicator, then this indicator to be the priority in improving the indicator followed by other indicators sequentially according to the gap score.

Table 5. The category of customer satisfaction index

\begin{tabular}{ccc}
\hline No & Index Value & Category \\
\hline 1 & $81 \%-100 \%$ & Very Satisfied \\
2 & $66 \%-80.99 \%$ & Satisfied \\
3 & $51 \%-65.99 \%$ & Quite Satisfied \\
4 & $35 \%-50.99 \%$ & Slightly Satisfied \\
5 & $0 \%-34.99 \%$ & Not Satisfied \\
\hline
\end{tabular}

Meanwhile, to find out the overall level of satisfaction of users, the CSI is used. Table 5 is a category of CSI that consists of 5 categories that refer to the study of [23]. The categories can be described as Very Satisfied category with the index value at $81 \%-100 \%$, the Satisfied category with the index value at $66 \%-80.99 \%$, the Quite Satisfied category with the index value of $51 \%-65.99 \%$, the Slightly Satisfied category with the index value at 35\% - $50.99 \%$ and Not Satisfied category with the index value at $0 \%$ $-34.99 \%$. The CSI calculation results in table 4 show a value of $77.37 \%$. By referring to table 5 , this CSI value is included in the category with the Satisfied category.

\section{Conclusion}

The results showed that the use of Servqual can be applied to determine the level of user satisfaction to academic information system services at the State University of Surabaya. The Servqual method in this study can help to determine the level of user satisfaction through the use of the CSI formula. It addition, the use of the CSI formula produces a value of $77.37 \%$, so it can be concluded that the satisfaction of users of academic information systems is in the satisfied category. Furthermore, decision-makers can improve the Servqual dimension, where the gap value is large to be corrected. By doing Quality Improvement, it is expected that the service level can increase to a Very Satisfied category.

\section{References}

[1] Shahin, Arash, "SERVQUAL and Model of Service Quality Gaps: A Framework for
Determining and Prioritizing Critical Factors in Delivering Quality Services", in Partha Sarathy, V. (ed), Service Quality - An Introduction, Andhra Pradesh: ICFAI University Press, pp. 117-131, 2006.

[2] Qadri U.A., 'Measuring Service Quality Expectation and Perception Using SERVQUAL: A Gap Analysis,” Bus Eco Journal, 6(162), 2015. doi:10.4172/2151- 6219.1000162

[3] Namin, Ardeshir \& Pilevary, Niko \& Namin, Aidin. "Measuring customer satisfaction using SERQUAL survey." Management Science Letters. 2, 933-938, 2012. 10.5267/j.msl.2011.10.011.

[4] Ivana Blesiae, Ivkov-Dzigurski, Andjelija Stankov, Ugijesa Stamenkovia Igor Bradiae, 'Research of Expected and Perceived Service Quality in Hotel Management. Revista de Turism: Studii si Cercetari in Turism," Journal of Tourism - Studies and Research in Tourism · June 2011

[5] Ren, L., Qiu, H., Wang, P., \& Lin, P. M. C., 'Exploring customer experience with budget hotels: Dimensionality and satisfaction," International Journal of Hospitality Management, 52, 13-23, 2016. doi:10.1016/j.ijhm.2015.09.009

[6] Siti Husna Ainu S., 'Penerapan Customer Satisfaction Index (CSI) dan Analisis Gap pada Kualitas Pelayanan Trans Jogja,' Jurnal Ilmiah Teknik industri, 13(2), 103-111, 2014.. DOI:

[7] Budhi I Gede, KT. Tjahyadi Putra, Ni Kadek Sumiari, "Pengukuran Customer Satisfaction Index Terhadap Pelayanan di Century Gym," Jurnal Ilmiah SISFOTENIKA. 7(1), 2017.

[8] Vijayanand Sundaram, D. Ramkumar, Poorna Shankar. "Impact of E-Service Quality on Customer Satisfaction and Loyalty Empirical Study in India Online Business.” Kinerja, 21(1), 48-69, 2017.

[9] Army Justitia, Rini Semiati, Nadhila Ramadhini Ayuvinda. "Customer Satisfaction Analysis of Online Taxi Mobile Apps.” Journal of Information Systems Engineering and Business Intelligence, 5(1), April 2019.

[10] Hamda S. Al-Neyadi, Salam Abdallah, Mohsin Malik. 'Measuring patient's satisfaction of healthcare services in the UAE hospitals: Using SERVQUAL," International Journal of Healthcare Management, 11, 2018.

[11] Michael Stodnick, Pamela Rogers, 'Using SERVQUAL to Measure the Quality of the Classroom Experience," Decision Sciences Journal of Innovative Education, 6 (1), 2008.

[12] Purwaningsih D., "Assessing the Effects of Service Quality of Government and Student Satisfaction in Education's Field.” IOP Conf. Series: Materials 
Science and Engineering, 180, 2017. 012003 doi:10.1088/1757-899X/180/1/012003

[13] Costas Zafiropoulos, Vasiliki Vrana. 'Service quality assessment in a Greek higher education institute," Journal of Business Economics and Management, 9(1), 33-45, 2008.

[14] Stefano, N.M, Casarotto Filho, N., Barichello, R., Sohn, A.P. 'A fuzzy SERVQUAL based method for evaluated of service quality in the hotel industry." 7th Industrial Product-Service Systems Conference - PSS, industry transformation for sustainability and business. Procedia CIRP 30, $433-438,2015$.

[15] Hafidz Surapranata and BudiPermadi Iskandar., "Evaluation of customer satisfaction using service quality dimension at d'seuhah da lada restaurant." Journal of Business and Management, 2(1), 1428, 2013.

[16] Parisa Akhtari, Amir Parviz Akhtari and Ahmad Torfi. "Measuring customer satisfaction in food industry." Management Science Letters, 5, 235244, 2015

[17] Muhammad Ali, Syed Ali Raza, 'Service quality perception and customer satisfaction in Islamic banks of Pakistan: the modified SERVQUAL model," Total Quality Management \& Business Excellence, 2015. DOI: 10.1080/14783363.2015.1100517

[18] Rahim Hussain, Amjad Al Nasser, Yomna K. Hussain, 'Service quality and customer satisfaction of a UAE-based airline: An empirical investigation." Journal of Air Transport Management, 42, 167-175, 2015.

[19] Angelova, Biljana \& Zeqiri, Jusuf. "Measuring Customer Satisfaction with Service Quality Using American Customer Satisfaction Model (ACSI Model)." International Journal of Academic Research in Business and Social Sciences, 1, 2011.

[20] Yang, H. and Chen, K.S. , "A performance index approach to managing service quality», Managing Service Quality: An International Journal, 10(5), 273-278, 2000

[21] Aritonang, R.L. 2005. Kepuasan Pelanggan. Jakarta: Gramedia.

[22] Parasuraman , A. Zeithaml, V., Berry, L.L. "SERVQUAL: A Multiple-Item Scale for Measuring Consumer Perceptions of Service Quality.” Journal of Retailing, 64(1), 12-40, 1988.

[23] Fitriana, D., Florencia Y. K. O., Jati, U. D. H., \& Tanto, D. S, 'Pengukuran kepuasan kontraktor terhadap kinerja klien pada proyek kontruksi swasta.” Jurnal Karya Teknik Sipil, 3(1), 283-295, 2014. 